\title{
The Role of Branding on Educational Performance in the Egyptian Private Universities
}

\author{
Amel Rashwan, Ayman Shawky, Mohamed A. Ragheb, Alaa A. Bary \\ Graduate School of Business, AAST, Alexandria, Egypt \\ Email: amelalsayeddba@gmail.com
}

How to cite this paper: Rashwan, A., Shawky, A., Ragheb, M.A. and Bary, A.A. (2018) The Role of Branding on Educational Performance in the Egyptian Private Universities. Open Access Library Journal, 5: e4882. https://doi.org/10.4236/oalib.1104882

Received: September 5, 2018

Accepted: October 12, 2018

Published: October 15, 2018

Copyright (C) 2018 by authors and Open Access Library Inc.

This work is licensed under the Creative Commons Attribution International License (CC BY 4.0).

http://creativecommons.org/licenses/by/4.0/

(c) (i) Open Access

\begin{abstract}
This paper aims to investigate the role of branding in achieving a good performance level for Egyptian universities. It explains the value of impact of each dimension of the Branding, which are: Design, Communication and Feedback, on Performance, represented in Alumni, Employment and Learning Efficiency. Regression analysis and SEM were conducted and results show that none of the Branding dimensions significantly affects Learning Efficiency. On the other hand, all Branding dimensions are significantly affecting Alumni. It could be concluded that there should be some enhancements regarding the programs provided for post graduates to be able to achieve the required level of learning efficiency.
\end{abstract}

\section{Subject Areas}

Education

\section{Keywords}

Branding, Performance, Private Universities, Education, Design

\section{Introduction}

Educational sector in Egypt is facing many challenges nowadays in several issues. Several researches had been done to improve the performance of educational institutes but still it is not as appropriate enough to achieve the desired level. Researches had been done to show that such branding capabilities could achieve a competitive advantage for educational institutes [1]. Most researches highlight the relationship between branding and companies' competitive advantage but few of them focus on the impact of this on performance [2]. 


\section{Literature Review}

Branding is an integral part of marketing strategy; it is the creation of a corporate identity and reputation. Because branding efforts are not limited to "consumer" products, firms in various service industries have been trying to utilize branding strategies to build stronger brands. In this regard, higher education and universities have also begun to realize the need to develop sustainable brand strategies. Therefore, branding has become a strategic issue and focus for universities and other post-compulsory educational institutions in order to develop meaningfully differentiated brands to communicate their strengths [3].

Recently, the economic environment has had a major negative impact on the financial situation of most higher education institutions. More enduring is that vast numbers of universities and colleges (i.e. brands) in the marketplace often compete for the same students. Moreover, the relatively simple promotional tools of the past no longer work as they once did. As today's prospective students are fully immersed in a variety of digital worlds, institutions of higher education sometimes struggle to understand and embrace their needs. It is in this context that colleges and universities are turning to branding as they seek to thrive, and in some cases to survive [4].

Branding strategy is defined as the way companies mix and match their corporate, house, family and individual brand types for their products or services. This mix and match of brand types generates a variety of options for the companies from which they can select a suitable branding strategy for a product/service. An appropriate branding strategy is crucial as it would reinforce the desired positioning and hence influence purchase behavior. Unfortunately, even the best brand managers have struggled to choose the most appropriate branding strategy, in part, due to a lack of academic clarity and study. Neither type of branding strategy is better than the other; rather suitability of the branding strategy depends on the matching of the branding strategy with the characteristics of the offering. Based on inherent product category characteristics such as risk, involvement, purchase transaction amount, and frequency of purchase etc. [5].

Corporate Brands: A key precept of this article is that corporate brands can be regarded as a distinct identity type. To reiterate, corporate brands are associated with key corporate associations and expectations, which are evoked by a corporate name and or logo. A corporate brand is separate and divisible from an organization's corporate identity: the latter-a corporate identity-refers to an institution's Defining, Distinctive and Differentiated institutional attributes. Within the literature, there is growing consensus that the corporate brand should be closely calibrated with the corporate identity. It was asserted, for instance, that the building of corporate identity underpins corporate brand management [6].

Corporate brands have been characterized as follows: The corporate branding philosophy, at its core, represents an explicit covenant between an organization 
and its key stakeholder groups including customers. The covenant is set forth by senior management in terms of a clearly articulated corporate branding proposition. It is professed via the multiple channels of communication. It is experienced through corporate and staff behavior, and, importantly, through the organization's products and/or services. A corporate brand, although it creates awareness and recognition via a name of logo, needs to articulate its accord with key stakeholders by demonstrating, unceasingly and over time that it has kept its corporate branding pledge. As such it became a mark of assurance [7]. Corporate branding provides a mechanism for developing this cultural emphasis. The goal of corporate branding is to conceive, manage and communicate corporate brand values in order to guide managerial decisions, actions and normative firm behavior [8].

Since corporate brand values originate from organizational heritage and culture, and guide employee behaviors, they enable the company as a whole to unite behind a particular strategic intent. However, corporate brand values and the way that they are translated into staff behaviors and conveyed to customers and other stakeholders are generally overlooked in existing studies of market driving, although some contributions use examples of companies with strong corporate brands to illustrate this approach. When internationalization is involved, it is also important to consider a firm's actions at both the global and the local levels. A market driving strategy applied in a local market is more likely to succeed if supported by a clear and consistent global brand vision, and a value laden resource base that can be mobilized and implemented at the local level [9].

Corporate Branding allows luxury firms to create distinguishable brands in return for customers' preferences and loyalty [10]. Doing so highlights the strategic, relational nature of place branding. The authors focus specifically on firstand zero-order capabilities, integrating absorptive capacity (first-order) and an innovation capability (zero-order) into a place branding framework. We define an innovation capability within a place branding context and offer absorptive capacity as a mechanism through which DMO leaders can exploit external knowledge acquisition [11]. Service branding studies often stress the importance of internal aspects of branding. Indeed, employee branding is effective when employees internalize the brand image and are motivated and empowered to project it to customers and other stakeholders [12]. However, employee branding becomes ineffective if the brand does not reflect reality [13].

On the other hand, internal branding helps an institution overcome internal resistance to branding efforts. It helps the institution take an identity-development strategy beyond traditional approaches, such as new logos, snappy taglines and expensive advertising campaigns, to an embedded cultural approach that guides everything from communications, fund-raising, marketing and personnel policies to enrollment management and program development [14].

Country Branding (also known as nation branding): it is the creation of a dif- 
ferentiated identity in targeted international markets through the use of name, logo and other branding elements. The definition of nation branding was "the strategic self-presentation of a country with the aim of creating reputational capital through economic, political and social interest promotion at home and abroad" [15].

Branding is considered to be one of the most important assets of any institution. Corporate brand management plays a critical role in forming positive attitudes towards the institution. The intangibility and inseparability of HE services makes branding even more important. The importance of the development and management of a distinctive brand helps to create and maintain a competitive advantage in the HE sectors. The management of the corporate brand, which consists of periodic audits, is one of the most important tasks. Currently, branding in HE has become an increasingly essential issue with substantial commitment of financial resources allocated to branding activities. However, the degree of importance of corporate branding varies between different institutions as well as countries [16].

There is evidence in the literature that suggests that organizations struggle to formulate and implement their corporate branding strategies. This might be due to its paradoxical complexity, the newness of the field, and its cross disciplinary nature [17]. Many organizations are unsure of how to manage their corporate brands. Much of the work has been theoretical and there has been limited empirical investigation [18].

[19] suggests that firms branding capabilities can be understood along two dimensions: internal related (comprising asset-related and knowledge-related capabilities) and external driven (comprising of market factors and institutional factors). Additionally, [20] also puts across their perspective of branding capabilities to embrace three facets. They include a firms' ability to design high-performance products at competitive prices, the ability to carry out fruitful, beneficial collaborations with stakeholders, and the ability to communicate the component brand at low cost.

Furthermore, [21] describes branding capability to comprise four approaches: identifying brand meaning; using branding as an operational tool; communicating consistent brand meaning and; getting staff to support the brand [22]. Another considered measurement for Branding Capability, is that it can be conceptualized as brand value (inertia) plus change [23].

Brands have become an increasingly valuable marketing tool in a crowded marketplace because they allow consumers to distinguish sellers and goods and make choices based on information that is more reliable [24]. The term brand is defined as a complex symbol representing a variety of ideas and attributes that build up in the minds of consumers over time, whose legal term is trademark; the brand is fundamental for competitiveness and long-term survival. Moreover, brand personality might be, in some cases, more important than technical features of the product. 
From an academic point-of-view, this issue has been under-investigated, apart from few studies [25], which focus on large corporations and generally show a positive impact of brand and trademark activities on firm economic and financial performance. Further, even though small and medium-size enterprises (SMEs) account for 95 per cent of the business population, and recently provide evidence of stronger brand investments [26], studies on the relationship between marketing activities and firms' performance have not taken them into consideration [27].

Branding industrial services organizations requires a special approach. First, service provider selection is a strategic choice. Second, the interaction between the buyer and the industrial service provider is highly complex and long-lasting. It was suggested that corporate branding is more suitable for services companies than service branding, owing to the inherent difficulties of differentiating between services. In corporate branding the whole firm is mobilized to participate in branding and the brand is used to influence both customers and other stakeholders. Thus, although opposing views have been presented, research strongly supports the particularities of branding industrial services companies with corporate branding strategy [28].

Literature has long recognized that firm capabilities (such as branding capabilities) are vital impetuses for organizational performance [29]. In spite of the burgeoning state of branding studies, however, three key deficiencies are observed in marketing literature. First, a significant gap exists regarding the amount of branding research focusing on small- and medium-sized enterprises (SMEs) in comparison with those carried out with large organizations settings [30]. Second, the branding literature exhibits a paucity of research works emanating from emerging or less-developed economies compared to those from developed economic settings [31]. In addition to this, management research and institutional theory recognizes that the functions of firm capabilities are likely to fluctuate with the nature of market environments [32].

Although the definition of branding capability is not firmly rooted in literature, a number of conceptualizations on what it constitutes have been put across by scholars. [33] conceptualizes branding capability as a firm's capacity to marshal a bundle of interrelated organizational routines to perform activities such as communication, and marketing programs in delivering a consistent brand meaning with customers. [19] suggests that firms' branding capabilities can be understood along two dimensions: internal related (comprising asset-related and knowledge-related capabilities) and external driven (comprising of market factors and institutional factors). Additionally, [20] also puts across their perspective of branding capabilities to embrace three facets. They include a firm's ability to design high-performance products at competitive prices, the ability to carry out fruitful, beneficial collaborations with stakeholders, and the ability to communicate the component brand at low cost. Furthermore, [21] describes branding capability to comprise four approaches: identifying brand meaning; using branding as an operational tool; communicating consistent brand meaning and; 
getting staff to support the brand.

From the various conceptualizations, a broader theorization may suggest that firms do not only select brand elements/identities but also incorporate marketing mix programs and communications, as well as leverage on secondary associations when implementing branding efforts [34]. These branding efforts are developed through learning and configuration mechanisms, which continually shape firms' competencies and can be sources of sustainable competitive advantage because they are not easy to replicate, imitate or learn.

Therefore, branding capabilities are not only generated internally within firms but also attainable from external parties. The latter form of branding capabilities is particularly important for firms in emerging economies, where institutional, social and market changes take place more rapidly [19] amidst lingering shortage of resources, unbridled competition and inadequate infrastructure [35].

Therefore, branding activities could be classified as company values and ideas, designing, stabilizing, communication, networking and feedback [13].

\section{Methodology}

The current research is an explanatory quantitative research using the questionnaire survey, as it will explain the impact of branding capability on educational institutes performance. Research variables are classified as the Branding Capabilities, representing the independent variable, Educational Institutes performance, representing the dependent variable. The questionnaire statements depend on using a five-point Likert scale will be adopted for research variables to be able to evaluate the educational institutes' performance. The research strategy sheds the light on some of the findings of survey that will be conducted in private universities in Egypt. It will intend to gather information about the educational performance and the educational process in Egyptian universities to help in achieving the higher educational performance of educational sector in Egypt.

The research hypothesis could be stated as follows:

H1: There is a significant impact of Branding on Alumni.

H2: There is a significant impact of Branding on Employment.

H3: There is a significant impact of Branding on Learning Efficiency.

\section{Results and Findings}

This section will present the validity and reliability testing of the research variables, descriptive analysis of the research variables, and hypothesis testing using regression analysis and structural equation modeling (SEM).

Validity and reliability tests are two requirements to prove the accuracy of results extracted from the questionnaire. Therefore, validity and reliability tests were performed to ensure that the data is adequate for analysis. Validity refers to the extent of accuracy of the results of the study. It could be either internal or external. Internal validity refers to the analysis of the accuracy of the results obtained, while external validity refers to the analysis of the findings with regards 
to whether they can be generalized [36]. The validity of the data could be confirmed when the Average Variance Extracted (AVE) of all quality factors are greater than or equal to $50 \%$ and all items loadings are greater than 0.4 [37]. Reliability refers to the internal consistency between the items selected to measure one variable. Cronbach's alpha value is one common measurement of reliability. The higher the Cronbach's a value, the higher is the internal consistency, where the minimum value for acceptable reliability is above 0.7 [38].

Table 1 shows the validity and reliability tests for the Knowledge Sharing and its dimensions for the trainees receiving ECDIS generic training, where all AVEs and item loadings are above these cut-off values, implying adequate validity for the data under study. It also shows that all Cronbach's alpha values for this study exceed 0.7 , implying that the data is reliable.

Table 2 shows the mean and standard deviation of the research variables, as well as the corresponding frequencies for the responses of the Educational Institutes' Performance. It was noticed that the mean values of all the research variables are above average of 2.5. Also, all frequencies of research variables are relatively lying in the zones of neutral and agree.

Table 3 displays the results of the regression analysis of Educational Institutes' Performance; Program Design, Communication, and Feedback on "Alumni". The multiple regression analysis shows that there is a significant impact of Program Design on Alumni, as p-value is 0.000 . Similarly, Communication ( $\mathrm{p}$-value $=$ 0.001) shows a significant impact on Alumni, Similarly, Time ( $\mathrm{p}$-value $=0.000)$ shows a significant impact on Alumni. Moreover, the table shows that Program Design, Communication and Feedback explain 36.2\% of the variation in Alum$\mathrm{ni}$, as R Square is 0.362 .

Table 4 displays the results of the regression analysis Educational Institutes' Performance; Program Design, Communication, and Feedback on "Student Employment". The multiple regression analysis shows that there is a significant impact of Program Design on Student Employment, as p-value is 0.000. Similarly, Communication ( $\mathrm{p}$-value $=0.000$ ) shows a significant impact on Student Employment, while Feedback ( $\mathrm{p}$-value $=0.640>0.05$ ) has an insignificant impact on Student Employment. Moreover, the table shows that Program Design, Communication and Feedback explain $27.9 \%$ of the variation in Student Employment, as R Square is 0.279 .

Table 5 displays the results of the regression analysis Educational Institutes' Performance; Program Design, Communication, and Feedback on "Learning Efficiency". The multiple regression analysis shows that there is insignificant impact of Program Design on Student Efficiency, as p-value is 0.149. Similarly, Communication ( $\mathrm{p}$-value $=0.704)$ shows insignificant impact on Learning Efficiency, Similarly, Feedback (p-value $=0.153>0.05$ ) has an insignificant impact on Learning Efficiency. Moreover, the table shows that Program Design, Communication and Feedback explain 0\% of the variation in Student Employment, as R Square is 0007. 
Table 1. Validity and reliability tests for the research variables.

\begin{tabular}{|c|c|c|c|c|}
\hline Variable & Item & AVE & Factor Loading & Cronbach's Alpha \\
\hline \multirow{5}{*}{ Program Design } & Item 1 & \multirow{5}{*}{$62.842 \%$} & 0.632 & \multirow{5}{*}{0.844} \\
\hline & Item 2 & & 0.506 & \\
\hline & Item 3 & & 0.584 & \\
\hline & Item 4 & & 0.852 & \\
\hline & Item 5 & & 0.567 & \\
\hline \multirow{5}{*}{ Communication } & Item 1 & \multirow{5}{*}{$58.831 \%$} & 0.518 & \multirow{5}{*}{0.820} \\
\hline & Item 2 & & 0.519 & \\
\hline & Item 3 & & 0.732 & \\
\hline & Item 4 & & 0.574 & \\
\hline & Item 5 & & 0.598 & \\
\hline \multirow{4}{*}{ Feedback } & Item 1 & \multirow{4}{*}{$64.372 \%$} & 0.643 & \multirow{4}{*}{0.814} \\
\hline & Item 2 & & 0.601 & \\
\hline & Item 3 & & 0.695 & \\
\hline & Item 4 & & 0.636 & \\
\hline \multirow{3}{*}{ Student Alumni } & Item 1 & \multirow{3}{*}{$66.141 \%$} & 0.663 & \multirow{3}{*}{0.742} \\
\hline & Item 2 & & 0.575 & \\
\hline & Item 3 & & 0.746 & \\
\hline \multirow{3}{*}{ Student Employment } & Item 1 & \multirow{3}{*}{$68.170 \%$} & 0.677 & \multirow{3}{*}{0.766} \\
\hline & Item 2 & & 0.627 & \\
\hline & Item 3 & & 0.742 & \\
\hline \multirow{3}{*}{ Student Efficiency } & Item 1 & \multirow{3}{*}{$63.611 \%$} & 0.585 & \multirow{3}{*}{0.713} \\
\hline & Item 2 & & 0.640 & \\
\hline & Item 3 & & 0.683 & \\
\hline \multirow{5}{*}{ Program Design } & Item 1 & \multirow{5}{*}{$62.842 \%$} & 0.632 & \multirow{5}{*}{0.844} \\
\hline & Item 2 & & 0.506 & \\
\hline & Item 3 & & 0.584 & \\
\hline & Item 4 & & 0.852 & \\
\hline & Item 5 & & 0.567 & \\
\hline \multirow{5}{*}{ Communication } & Item 1 & \multirow{5}{*}{$58.831 \%$} & 0.518 & \\
\hline & Item 2 & & 0.519 & \\
\hline & Item 3 & & 0.732 & 0.820 \\
\hline & Item 4 & & 0.574 & \\
\hline & Item 5 & & 0.598 & \\
\hline & Item 1 & & 0.643 & \\
\hline Feedhack & Item 2 & $64372 \%$ & 0.601 & 0814 \\
\hline Fetudack & Item 3 & $04.072 \%$ & 0.695 & 0.014 \\
\hline & Item 4 & & 0.636 & \\
\hline & Item 1 & & 0.663 & \\
\hline Student Alumni & Item 2 & $66.141 \%$ & 0.575 & 0.742 \\
\hline & Item 3 & & 0.746 & \\
\hline & Item 1 & & 0.677 & \\
\hline Student Employment & Item 2 & $68.170 \%$ & 0.627 & 0.766 \\
\hline & Item 3 & & 0.742 & \\
\hline & Item 1 & & 0.585 & \\
\hline Student Efficiency & Item 2 & $63.611 \%$ & 0.640 & 0.713 \\
\hline & Item 3 & & 0.683 & \\
\hline
\end{tabular}


Table 2. Descriptive analysis of the research variables of educational institutes' performance.

\begin{tabular}{cccccccc}
\hline \multirow{2}{*}{ Variable } & Mean & Std. Deviation & \multicolumn{5}{c}{ Frequency } \\
\cline { 4 - 8 } & & & $\mathbf{1}$ & $\mathbf{2}$ & $\mathbf{3}$ & $\mathbf{4}$ & $\mathbf{5}$ \\
\hline Program Design & 3.1161 & 0.88987 & 23 & 72 & 196 & 144 & 13 \\
Communication & 3.3371 & 0.91484 & 19 & 56 & 152 & 197 & 24 \\
Feedback & 3.0647 & 0.95903 & 25 & 91 & 1888 & 118 & 26 \\
Alumni & 3.1964 & 0.87305 & 10 & 76 & 207 & 126 & 29 \\
Student Employment & 3.1496 & 0.91101 & 20 & 74 & 196 & 135 & 23 \\
Student Efficiency & 2.8504 & 0.84475 & 23 & 124 & 203 & 93 & 5 \\
\hline
\end{tabular}

Table 3. Regression analysis of independent variables on alumni.

\begin{tabular}{ccccccc}
\hline \multirow{2}{*}{ Variable } & \multicolumn{2}{c}{ Unstandardized Coefficients } & & \multirow{2}{*}{$\mathbf{t}$} & P-value & R Square \\
\cline { 2 - 4 } & B & Std. Error & & & \\
\hline (Constant) & 1.091 & 0.139 & 7.866 & 0.000 & \\
Program Design & 0.262 & 0.050 & 5.204 & 0.000 & 0.362 \\
Communication & 0.165 & 0.049 & 3.403 & 0.001 & \\
Feedback & 0.241 & 0.045 & 5.347 & 0.000 & \\
\hline
\end{tabular}

Table 4. Regression analysis of independent variables on student employment.

\begin{tabular}{|c|c|c|c|c|c|}
\hline \multirow{2}{*}{ Variable } & \multicolumn{2}{|c|}{ Unstandardized Coefficients } & \multirow{2}{*}{$\mathrm{t}$} & \multirow{2}{*}{ p-value } & \multirow{2}{*}{ R Square } \\
\hline & B & Std. Error & & & \\
\hline (Constant) & 1.248 & 0.154 & 8.107 & 0.000 & \multirow{4}{*}{0.279} \\
\hline Program Design & 0.272 & 0.056 & 4.886 & 0.000 & \\
\hline Communication & 0.337 & 0.054 & 6.249 & 0.000 & \\
\hline Feedback & -0.023 & 0.050 & -0.468 & 0.640 & \\
\hline
\end{tabular}

Table 5. Regression analysis of independent variables on learning efficiency.

\begin{tabular}{|c|c|c|c|c|c|}
\hline \multirow{2}{*}{ Model } & \multicolumn{2}{|c|}{ Unstandardized Coefficients } & \multirow{2}{*}{$\mathrm{t}$} & \multirow{2}{*}{$\mathrm{p}$-value } & \multirow{2}{*}{ R Square } \\
\hline & B & Std. Error & & & \\
\hline (Constant) & 2.891 & 0.167 & 17.264 & 0.000 & \multirow{4}{*}{0.007} \\
\hline Program Design & 0.088 & 0.061 & 1.445 & 0.149 & \\
\hline Communication & -0.022 & 0.059 & -0.381 & 0.704 & \\
\hline Feedback & -0.078 & 0.054 & -1.433 & 0.153 & \\
\hline
\end{tabular}

Table 6 displays the results of the regression analysis of Educational Institutes' Performance; Program Design, Communication, and Feedback on "Alumni". The multiple regression analysis shows that there is a significant impact of Program Design on Alumni, as p-value is 0.000. Similarly, Communication ( $\mathrm{p}$-value $=0.000)$ shows a significant impact on Alumni, Similarly, Time (p-value $=0.000)$ shows a significant impact on Alumni. Moreover, the table shows that 
Program Design, Communication and Feedback explain 50.8\% of the variation in Alumni, as R Square is 0. 508. Also, displays the results of the regression analysis of Educational Institutes' Performance; Program Design, Communication.

Also, displays the results of the regression analysis; Program Design, Communication, and Feedback on "Student Employment". The multiple regression analysis shows that there is a significant impact of Program Design on Student Employment, as $\mathrm{p}$-value is 0.000 . Similarly, Communication $(\mathrm{p}$-value $=0.000)$ shows a significant impact on Student Employment, while Feedback ( $\mathrm{p}$-value = $0.637>0.05$ ) has an insignificant impact on Student Employment.

Moreover, Table 7 shows that Program Design, Communication and Feedback explain $39.8 \%$ of the variation in Student Employment, as R Square is 0. 398. Also, it displays the results of the regression analysis; Program Design, Communication, and Feedback on "Student Efficiency". The multiple regression analysis shows that there is insignificant impact of Program Design on Student Efficiency, as p-value is 0.274 . Similarly, Communication ( $\mathrm{p}$-value $=0.789$ ) shows

Table 6. Research model SEM output.

\begin{tabular}{rccc}
\hline & & Estimate & p-Value \\
\hline Program Design & Alumni & 0.257 & 0.000 \\
Program Design & Employment & 0.271 & 0.000 \\
Program Design & Learning Efficiency & 0.074 & 0.274 \\
Communication & Alumni & 0.213 & 0.002 \\
Communication & Student Employment & 0.421 & 0.000 \\
Communication & Learning Efficiency & -0.018 & 0.789 \\
Feedback & Alumni & 0.292 & 0.000 \\
Feedback & Student Employment & -0.034 & 0.637 \\
Feedback & Learning Efficiency & -0.063 & 0.338 \\
Program Design & Alumni & 0.257 & 0.000 \\
Program Design & Employment & 0.271 & 0.000 \\
Program Design & Learning Efficiency & 0.074 & 0.274 \\
Communication & Alumni & 0.213 & 0.002 \\
Communication & Student Employment & 0.421 & 0.000 \\
Communication & Learning Efficiency & -0.018 & 0.789 \\
Feedback & Alumni & 0.292 & 0.000 \\
Feedback & Student Employment & -0.034 & 0.637 \\
Feedback & Learning Efficiency & -0.063 & 0.338 \\
\hline
\end{tabular}

Table 7. SEM fit indices.

\begin{tabular}{ccccc}
\hline CMIN/DF & p-Value & GFI & CFI & REMSA \\
\hline 2.409 & 0.000 & 0.900 & 0.926 & 0.056 \\
\hline
\end{tabular}




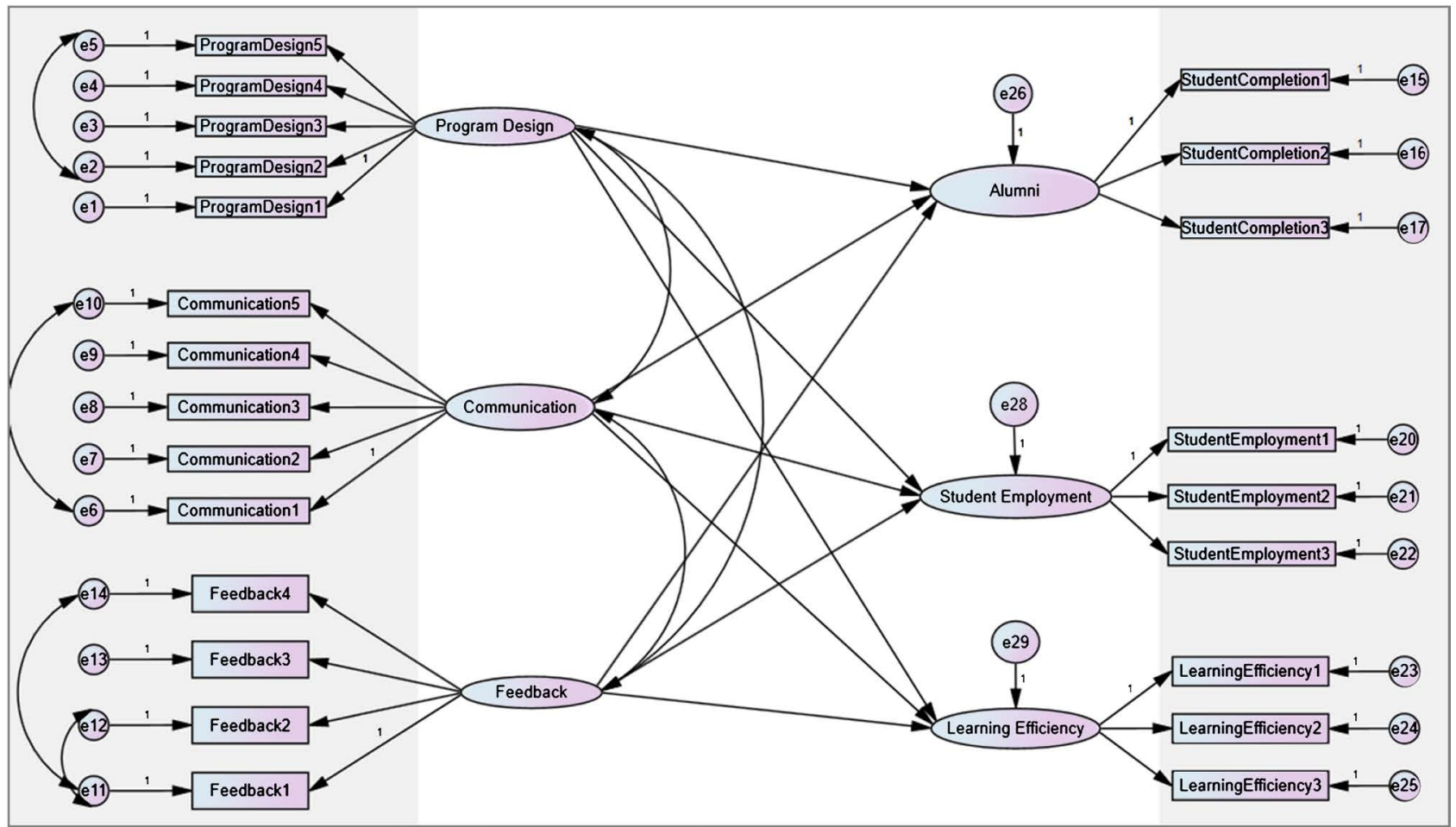

Figure 1. Research SEM model.

insignificant impact on Student Efficiency, Similarly, Feedback ( $\mathrm{p}$-value $=0.338>$ 0.05) has an insignificant impact on Student Efficiency. Moreover, the table shows that Program Design, Communication and Feedback explain 0\% of the variation in Student Employment, as R Square is 0.007 (Figure 1).

The model fit indices; $\mathrm{CMIN} / \mathrm{DF}=2.409, \mathrm{GFI}=0.900, \mathrm{CFI}=0.926$, and REMSA $=0.056$ are all within their acceptable levels.

\section{Conclusions}

The above results shed the light on the role of branding in the performance of the private universities. It could be concluded that there should be some enhancements regarding the programs provided for post graduates to be able to achieve the required level of learning efficiency. This result was observed as none of the branding dimensions affect the learning efficiency dimension.

Also, it could be observed that there is a significant role of branding in enhancing private universities performance level. This means that managers of private universities should focus on the program designs, as well as keeping on communicating with students and getting their feedback to improve program designs in turn and, in addition, increase students' completion and progression levels.

\section{Conflicts of Interest}

The authors declare no conflicts of interest regarding the publication of this paper. 


\section{References}

[1] Wæraas, A. and Solbakk, M.N. (2009) Defining the Essence of a University: Lessons from Higher Education Branding. Higher education, 57, 449.

https://doi.org/10.1007/s10734-008-9155-Z

[2] Gray, B.J., Fam, K.S. and Llanes, V.A. (2003) Branding Universities in Asian Markets. Journal of Product \& Brand Management, 12, 108-120. https://doi.org/10.1108/10610420310469797

[3] Jevons, C. (2006) Universities: A Prime Example of Branding Going Wrong. Journal of Product \& Brand Management, 15, 466-467. https://doi.org/10.1108/10610420610712856

[4] Pinar, M., et al. (2011) Utilizing the Brand Ecosystem Framework in Designing Branding Strategies for Higher Education. International Journal of Educational Management, 25, 724-739. https://doi.org/10.1108/09513541111172126

[5] Kaur, I. (2016) Online Buying Behaviour of College Going Students in Ludhiana City for Apparel Products. Punjab Agricultural University, Ludhiana.

[6] Hulberg, J. (2006) Integrating Corporate Branding and Sociological Paradigms: A Literature Study. Journal of Brand Management, 14, 60-73. https://doi.org/10.1057/palgrave.bm.2550054

[7] Balmer, J.M.T. (2012) Corporate Brand Management Imperatives: Custodianship, Credibility, and Calibration. California Management Review, 54, 6-33. https://doi.org/10.1525/cmr.2012.54.3.6

[8] Lawer, C. and Knox, S. (2006) Customer Advocacy and brand development. Journal of Product \& Brand Management, 15, 121-129. https://doi.org/10.1108/10610420610658956

[9] Burt, S. and Davies, K. (2010) From the Retail Brand to the Retailer as a Brand: Themes and Issues in Retail Branding Research. International Journal of Retail \& Distribution Management, 38, 865-878. https://doi.org/10.1108/09590551011085957

[10] Theng So, J., Parsons, A.G. and Yap, S.-F. (2013) Corporate Branding, Emotional Attachment and Brand Loyalty: The Case of Luxury Fashion Branding. Journal of Fashion Marketing and Management. An International Journal, 17, 403-423. https://doi.org/10.1108/JFMM-03-2013-0032

[11] Zavattaro, S. (2014) Place Branding through Phases of the Image: Balancing Image and Substance. Springer, Berlin. https://doi.org/10.1057/9781137394514

[12] Henkel, S., et al. (2007) Managing Brand Consistent Employee Behaviour: Relevance and Managerial Control of Behavioural Branding. Journal of Product \& Brand Management, 16, 310-320. https://doi.org/10.1108/10610420710779609

[13] Sandbacka, J., Nätti, S. and Tähtinen, J. (2013) Branding Activities of a Micro Industrial Services Company. Journal of Services Marketing, 27, 166-177. https://doi.org/10.1108/08876041311309270

[14] Whisman, R. (2009) Internal Branding: A University's Most Valuable Intangible Asset. Journal of Product \& Brand Management, 18, 367-370. https://doi.org/10.1108/10610420910981846

[15] Osei, C. and Gbadamosi, A. (2011) Re-Branding Africa. Marketing Intelligence \& Planning, 29, 284-304. https://doi.org/10.1108/02634501111129257

[16] Balmer, J. and Liao, M.-N. (2007) Student Corporate Brand Identification: An Exploratory Case Study. Corporate Communications. An International Journal, 12, 356-375. https://doi.org/10.1108/13563280710832515 
[17] Schultz, M., Yun, M.A. and Csaba, F.F. (2005) Corporate Branding: Purpose/People/Process: Towards the Second Wave of Corporate Branding. Copenhagen Business School Press, Copenhagen.

[18] Curtis, T., Abratt, R. and Minor, W. (2009) Corporate Brand Management in Higher Education: The Case of ERAU. Journal of Product \& Brand Management, 18, 404-413. https://doi.org/10.1108/10610420910989721

[19] Ni, N. and Wan, F. (2008) A Configurational Perspective of Branding Capabilities Development in Emerging Economies: The Case of the Chinese Cellular Phone Industry. Journal of Brand Management, 15, 433-451. https://doi.org/10.1057/bm.2008.10

[20] Altshuler, L. and Tarnovskaya, V.V. (2010) Branding Capability of Technology Born Globals. Journal of Brand Management, 18, 212-227. https://doi.org/10.1057/bm.2010.47

[21] Merrilees, B., Rundle-Thiele, S. and Lye, A. (2011) Marketing Capabilities: Antecedents and Implications for B2B SME Performance. Industrial Marketing Management, 40, 368-375. https://doi.org/10.1016/j.indmarman.2010.08.005

[22] Odoom, R., et al. (2017) Branding Capabilities and SME Performance in an Emerging Market: The Moderating Effect of Brand Regulations. Marketing Intelligence \& Planning, 35, 473-487. https://doi.org/10.1108/MIP-08-2016-0138

[23] Lei, X., Ye, T. and Abimbola, T. (2013) The Role of Branding Capability for Innovative Companies: Stock Market Reactions to New Product Announcement. Nankai Business Review International, 4, 329-348. https://doi.org/10.1108/NBRI-01-2013-0001

[24] Lemper, T.A. (2012) Five Trademark Law Strategies for Managing Brands. Business Horizons, 55, 113-117. https://doi.org/10.1016/j.bushor.2011.10.005

[25] Krasnikov, A., Jayachandran, S. and Kumar, V. (2009) The Impact of Customer Relationship Management Implementation on Cost and Profit Efficiencies: Evidence from the US Commercial Banking Industry. Journal of Marketing, 73, 61-76. https://doi.org/10.1509/jmkg.73.6.61

[26] Hughes, A. and Mina, A. (2010) The Impact of the Patent System on SMEs. Centre for Business Research, University of Cambridge, Cambridge.

[27] Helmers, C. and Rogers, M. (2008) Innovation and the Survival of New Firms across British Regions. Department of Economics Discussion Paper 416.

[28] Davis, D.F., Golicic, S.L. and Marquardt, A.J. (2008) Branding a B2B Service: Does a Brand Differentiate a Logistics Service Provider? Industrial Marketing Management, 37, 218-227. https://doi.org/10.1016/j.indmarman.2007.02.003

[29] Sok, P., O’Cass, A. and Sok, K.M. (2013) Achieving Superior SME Performance: Overarching Role of Marketing, Innovation, and Learning Capabilities. Australasian Marketing Journal, 21, 161-167. https://doi.org/10.1016/j.ausmj.2013.04.001

[30] Neuvonen, H. (2016) Toward a Model of Brand Strategy Adoption. Journal of Brand Management, 23, 197-215. https://doi.org/10.1057/bm.2016.6

[31] Odoom, R. (2016) Brand-Building Efforts in High and Low Performing Small and Medium-Sized Enterprises (SMEs). Journal of Small Business and Enterprise Development, 23, 1229-1246. https://doi.org/10.1108/JSBED-05-2016-0067

[32] Liang, H., et al. (2007) Assimilation of Enterprise Systems: The Effect of Institutional Pressures and the Mediating Role of Top Management. MIS Quarterly, 59-87. https://doi.org/10.2307/25148781

[33] O'Cass, A. and Ngo, L.V. (2011) Achieving Customer Satisfaction in Services Firms 
via Branding Capability and Customer Empowerment. Journal of Services Marketing, 25, 489-496. https://doi.org/10.1108/08876041111173615

[34] Keller, K.L. (2016) Reflections on Customer-Based Brand Equity: Perspectives, Progress, and Priorities. AMS Review, 6, 1-16.

[35] Sheth, J.N. (2011) Impact of Emerging Markets on Marketing: Rethinking Existing Perspectives and Practices. Journal of Marketing, 75, 166-182. https://doi.org/10.1509/jmkg.75.4.166

[36] Ghauri, P.N. and Grønhaug, K. (2005) Research Methods in Business Studies: A Practical Guide. Pearson Education, London.

[37] Fornell, C. and Larcker, D.F. (1981) Structural Equation Models with Unobservable Variables and Measurement Error: Algebra and Statistics. Journal of Marketing Research, 18, 382-388. https://doi.org/10.2307/3150980

[38] Hair Jr., J.F., et al. (2014) Partial Least Squares Structural Equation Modeling (PLS-SEM): An Emerging Tool in Business Research. European Business Review, 26, 106-121. https://doi.org/10.1108/EBR-10-2013-0128 